\title{
NOTAS SOBRE LA RELIGION EN EL TIEMPO DE LOS INCAS
}

\author{
LOUIS BAUDIN \\ (Protesor de la Universidad de París - Miembro del Instituto)
}

Es natural que en un país en el que la organización está fundada sobre un principio dualista, la religión presente un doble aspecto. Lo sobrenatural tiene la misma estructura que lo económico y lo administrativo. La jerarquía básica se establece en todos los dominios.

El hombre del pueblo (la masa) no tenía en el tiempo de los Incas, los mismos deberes, las mismas cargas, ni las mismas responsabilidades, que el hombre supericra (élite). Lógicamente no debía tener las mismas concepciones, Por otra parte, podemos, observar una distinción del mismo orden, pero mucho más confusa, entre muchas poblaciones actuales del sur de Europa: la religión del hombre de la calle es un poco pagana, se manifiesta por la adhesión a un santuario, a una estatua, o a un amuleto. La Virgen "del Pilar" no tiene los mismos poderes que la "Macarena" y sus méritos se comparan. El hombre cultivado, al contrario, se esfuerza en evocar la dignidad por encima de sus representaciones materiales.

El indio era, aun más que el hombre-masa actual, incapaz de elevarse a concepciones superiores por falta de posibilidad de análisis. Una de las formas más conocidas hoy día de la irracionalidad, es la globalidad. El indio precisamente tenía una vista global del mundo. Los cronistas son muy afirmativos sobre este punto. La parte del "cosmos", la de lo alto, la del centro, la de abajo, corresponden respectivamente al cielo, a la tierra, al interior de la tierra, y no forman sino un vasto conjunto flúido, continuo, homogéneo. No hay ya límites entre las formas como entre los reinos, los espacios y los tiempos. El paso de las fronteras aparentes es cuestión de poder psíquico. Aun hoy día, esta visión del mundo, subsiste sobre la meseta donde ella explica las supervivencias de hechicería. Quien sea fuerte para tentar la experiencia puede hacerse presente en varios lugares a la vez, enviar una parte de su cuerpo a otro 
sitio, encarnarse en un animal, descender el curso del tiempo para predecir el porvenir, etc. Nada está definido, todo se baña en la misma atmósfera vaporosa.

Los sociólogos han observado entre muchos primitivos ese "protoplasma ideológico", pero lo han hecho científicamente. Los españoles del siglo XVI, especialmente los misioneros, no han comprendido la lógica de este ilogismo. Miraron estas concepciones, sobre todo las prácticas que se derivan de ella, como maquinaciones del diablo. Los mitos y las leyendas se tuvieron por absurdos, nada menos. La mentalidad india se les escapó completamente.

Para la élite de la sociedad inca, la incomprensión española fué mayor aún. Nada podía ser más extraño a los conquistadores que la división bipartita de la religión. La idea de que podía haber un Dios para la élite y otros dioses para la masa, les había parecido risible, y sin embargo, algunos de ellos se asombraron ante el carácter abstracto de la divinidad adorada por los Incas que era superior a ellos. Garcilaso de la Vega, sin duda porque era de raza india, se aparta a este respecto de sus contemporáneos y proyecta un vivo resplandor sobre este oscuro dominio en el Capítulo VI del Libro Segundo de sus Comentarios Reales. Garcilaso sabe que entra en disidencia: "Los historiadores, dice él, abominan el hombre de Pachacamac, porque no comprenden el sentido... pero yo, que soy indio católico por la gracia divina, responderé a aquellos que me preguntaren cómo se llama Dios en mi lengua: Pachacamac, porque no hay otro nombre que este para designar a Dios en la lengua general del Perú. Todas las palabras que los historiadores empleen son impropias". El texto es fundamental. Garcilaso afirma que "el verdadero Dios" el Dios de los cristianos, era conocido de los nativos indios. Este Dios tenía un nombre, era adorado y no era ni Inca ni ninguno de los múltiples ídolos que figuraban en los templos. No era por" de pronto el Sol, divinizado sin embargo, ni nuestra madre la Tierra, ni el "poderoso" 0 el "anormal". Era una abstracción de una categoría superior comparable, y para Garcilaso idéntica, al Dios del que los españoles eran adoradores.

La religión popular ha sido objeto de numerosas observaciones de parte de los españoles de tiempos pasados y de numerosos estudios de los investigadores actuales de todas las naciones. No diremos nada de esas formas que son muy conocidas. Notaremos únicamente que la influencia de los Incas se ha ejercido sobre ella, a la vez con mucha prudencia y con mucho poderío. Dicho de otra manera ha ocurrido con la religión lo que con otras instituciones, la presión del poder central no ha sido brutal, revolucionaria, sino que ha sido continua y eficaz. La religión era, por otra parte, una de las instituciones imperiales. Bajo su aspecto popular, entraba en el cuadro de la política general y tendía a convertirse en una palanca de comando, como la jerarquía administrativa y la estadística. Era una religión dirigida y politiceada.

Nada de revolución, hemos dicho, puesto que los cultos locales eran respetados. Los soberanos no derribaban los ídolos de las tribus 
sometidas sino que los integraban en su propia religión. Era esta una gran habilidad: hacían de ellos sus rehenes.

Acción continua y eficaz, hemos agregado, puesto que los monarcas tendían a asegurar la unificación del imperio en todos los dominios: regímenes de la producción y de la repartición, lengua, fiestas, etc. El mejor medio desde este punto de vista era seguramente colocar a la cabeza jerarquía popular al Dios más admitido comunmente: el Sol, y hacer del sistema imperial una teocracia, considerando al Inca supremo como hijo del Sol. Por ahí, todo el régimen político y económico se colocaba bajo un signo divino, la ley era una orden de Dios, su violación resultaba un sacrilegio. El trabajo por cuenta del Estado formaba parte de un rito y tomaba el aspecto de un homenaje.

En cuanto a la religión de la élite, nos hallamos en presencia de una serie de puntos de interrogación. Sin duda alguna el Inca Supremo no era una divinidad para sus consejeros, ya que uno de ellos fué desposeído por aquéllos en razón de su cobardía, según Cieza de León (Parte Segunda. Cap. 39). El Sol no lo era tampoco para el Inca y sus pares que lo trataban familiarmente (según el Padre Cobo, Sarmiento y otros).

Seguramente también la concepción del Dios abstracto era muy depurada. Se necesitaba verdaderamente una mentalidad muy evolucionada para llegar a esta idea, que era absurdo ofrecer presentes y sacrificios a esta divinidad, puesto que ella lo poseía todo y a esta otra idea que la construcción de templos en su honor tenía poca significación en razón de su presencia universal. Dos edificios únicamente estaban consagrados al Todopoderoso. Uno en el Cuzco y el otro en Kacha. Reconozcamos que esta doble consecuencia, sacada por la élite de su noción de lo divino daba una idea extraordinariamente elevada de la mentalidad de sus miembros. Una sublimación religiosa semejante, un rechazo semejante de la forma, son impresionantes.

¿Debe creerse que a la manera de las grandes civilizaciones antiguas existía una iniciación que permitía a una super-élite traspasar los conocimientos de la propia élite, y penetrar en el misterio de las ciencias psíquicas? ¿Había una simbólica en los precitados templos del Cuzco y de Kacha? Sería necesario, como lo hace hoy día en Luxor un excelente equipo, notar y medir los menores detalles de las ruinas.

Que este Ser Supremo se haya llamado Wiracocha o Pachacamac. "El era adorado en el corazón" y no tenía representación material. He ahí lo esencial. En este dominio los Incas tienen, todavía, derecho a nuestra admiración. 